\title{
The Returns to Participation in the Nonfarm Sector in Rural Rwanda*
}

\author{
Andrew Dabalen, Stefano Paternostro, and Gaëlle Pierre
}

\begin{abstract}
In this paper, we investigate the differences in outcomes (earnings and consumption) between individuals (households) who participate in the non-farm sector and those who do not. We use propensity score matching methods, where we create appropriate comparison groups of individuals and households. First we find that non-farm self-employed individuals in rural Rwanda have significantly higher earnings than farm workers and non-farm formal employees. Second, we show that the benefits to non-farm self-employment are much higher among the non-poor than among the poor. Third, we show that diversified households, those with a farm and a non-farm enterprise, are less likely to be poor. Finally, farm households who do not participate in the market have significantly lower consumption levels than households that do. However, the benefits to market participation appear to matter less for the poor than for the non-poor. We find little difference in expenditures between market participants and non-market participants, for comparable households in the bottom $40 \%$ of the expenditure distribution.
\end{abstract}

\section{World Bank Policy Research Working Paper 3462, December 2004}

The Policy Research Working Paper Series disseminates the findings of work in progress to encourage the exchange of ideas about development issues. An objective of the series is to get the findings out quickly, even if the presentations are less than fully polished. The papers carry the names of the authors and should be cited accordingly. The findings, interpretations, and conclusions expressed in this paper are entirely those of the authors. They do not necessarily represent the view of the World Bank, its Executive Directors, or the countries they represent. Policy Research Working Papers are available online at http://econ.worldbank.org.

\footnotetext{
* Corresponding author Gaëlle Pierre; World Bank, 1818 H Street, NW, Washington D.C.

20433, email: gpierre@worldbank.org; Andrew Dabalen, email adabalen@worldbank.org, World Bank; Stefano Paternostro, email spaternostro@,worldbank.org, World Bank. The authors received useful comments and are grateful to Quentin Wodon, Kene Ezemenari, and to participants at the 2004 CSAE conference on "Growth, poverty reduction and human development in Africa", in particular Geeta Kingdon.
} 


\section{Introduction}

In the Poverty Reduction Strategy Paper produced by the government of Rwanda (2002), rural development represents one of the pillars for the fight against poverty. In this context, the development of non-farm employment opportunities is emphasized and the definition of specific policies is broadly envisaged. However, the identification of specific measures requires first a better understanding of the non-farm sector in rural Rwanda ${ }^{1}$ and the constraints that currently undermine its expansion.

Non-farm sector development generally entails multiple benefits. For instance, the nonfarm sector may absorb a growing rural labor force that cannot be employed in the agricultural sector and it may slow down rural-urban migration. Similarly, non-farm sector expansion may enhance growth and promote a more equitable distribution of income (Lanjouw and Lanjouw, 2001) also by enabling more effective and beneficial income diversification opportunities for rural households (Reardon, 1997). ${ }^{2}$

These broad considerations become even more vital in the context of a country such as Rwanda, characterized by a high population density, small and fragmented land holdings, and large discrepancies between land holdings across households. As Clay et al. (1990) note, poorer Rwandans with little access to land would benefit greatly from participating in the non-farm sector, if given appropriate training, capital, and credit. Despite the compelling rationale for furthering non-farm policies in developing countries, the empirical evidence has been mixed. In particular, the development of the non-agricultural sector is at times found to be associated with increased inequality, whereby richer households are better able to benefit from non-farm opportunities. Consequently, any policy recommendations in this area require a good understanding of the specific country context so as to ensure equitable access to non-farm opportunities.

To provide such context, this paper relies on the Rwandan Integrated Household Living Conditions Survey (Enquête Intégrale sur les Conditions de Vie des Ménages au Rwanda or EICV) conducted by the Statistics Department of the Ministry of Finance and Economic Planning between October 1999 and July 2001 (Ministry of Finance, 2002). While the EICV - a multipurpose household survey - did not focus on the question of interest here, it is nonetheless based on a representative sample of the population and replete with information regarding Rwandan households.

After identifying the main determinants of participation in the non-farm sector, we use propensity score methods to investigate the differences in outcomes (earnings and consumption) between individuals (households) who engage in non-farm sector activities

\footnotetext{
${ }^{1}$ By non-farm sector, we mean both self-employment and wage work in non-farm activities. Rural non-farm self-employed and wage employees are defined as individuals who live in rural areas and work in the non-farm sector. We do not have information on where this activity is taking place. This means that some of these individuals may live in a rural area, but work in a urban area.

${ }^{2}$ Reardon (1997) suggests four possible advantages from wider income diversification: (1) reduction of income risk (due to the uncertainty linked to their farming activities) by ex ante diversification; (2) maintaining food security in the face of low farm productivity or shocks; (3) ex post diversification because of insurance market failure, and (4) earning cash income to finance farm investments in case of credit market failure.
} 
and those who do not. Our main finding are as follows. First non-farm self-employed individuals in rural Rwanda have significantly higher earnings than farm workers and non-farm formal employees. Second, the benefits to non-farm self-employment are much higher among the non-poor than the among the poor. Third, we show that diversified households, those with a farm and a non-farm enterprise, are less likely to be poor. Finally, farm households who do not participate in the market have significantly lower consumption levels than households that do. However, the benefits to market participation appear less palpable for the poor than for the non-poor. We find little difference in expenditures between market participants and non-market participants for comparable households in the bottom $40 \%$ of the expenditure distribution.

Following this introduction, section 2 provides background information on the non-farm sector in Rwanda; sections 3 and 4 describe the data used and the methodology implemented while section 5 presents the results of the analysis: first the determinants of non-farm sector participation are discussed and second the size of earnings differentials are examined as we compare outcomes for participants and non-participants in the nonfarm sector, at both the individual and household levels. Section 6 concludes by drawing policy implications to inform any future reform efforts.

\section{Data description}

For the analysis presented in this paper we use the Rwanda Household Living Conditions Survey (EICV). This survey provides information on a wide range of economic and social issues (e.g., unemployment, health, education, incomes, expenditure, subsistence agriculture, migration and access to services). It is modeled on the World Bank's Social Dimensions of Adjustment data collection and analysis format. ${ }^{3}$ The design was completed in 1997 and piloted in 1998; 6420 households were interviewed between October 1999 and July 2001.

The sample design is a stratified two-stage design with three main strata: (i) Kigali urban, (ii) other prefecture urban centers and (iii) rural prefecture. Stratum (iii) is further stratified into 11 sub-strata corresponding to each rural prefecture. Each stratum is divided into zones (EAs - enumeration areas - or PSUs - primary sampling units). In the first stage, in each stratum, EAs are selected with probability proportional to size (i.e. number of households). The second stage involves the selection of a random sample (by systematic sampling) of a fixed number of households for enumeration.

The survey questionnaire has 12 major sections, each covering a major social or economic topic. The household schedule is divided into two parts: Part A on household characteristics (demographics, education, health, employment, migration, housing, etc.) and Part B on agriculture, expenditure, income, household enterprises, etc. For rural areas, there is a third part on infrastructure access. Annex 2 describes how the variables that we use were constructed.

\section{The non-farm sector in Rwanda}

\footnotetext{
${ }^{3}$ See World Bank (1992).
} 
Contrary to what is generally found in developing countries and to what Clay et al. (1990) have found in Rwanda, the EICV data suggest that the non-farm sector participation in rural areas is small. Clay et al. (1990) find that approximately half $(47 \%)$ of farm households in Rwanda engage in some form of off-farm employment. This offfarm work is mostly carried out as agricultural wage laborers $(31 \%)$ on the farms of their neighbors, while the remaining $69 \%$ of household members' time in off-farm activities is spent in the rural non-farm sector, notably as artisans, laborers or in commerce -generally in small businesses. Over five percent of off-farm employment is held by government functionaries. We find that in 20012.4 percent of women with a primary occupation (and 3.4 percent of women with a secondary occupation) are active in the non-farm sector. For men, the proportions are 7.4 of men with a primary occupation and 8.2 percent of men with a secondary occupation.. These numbers are modest, especially for women and in comparison to what Clay et al. (1990) reported in their paper at the beginning of the 1990s. Moreover, income from non-farm sector activities on average accounts for 20 percent of household income - one of the lowest shares among developing and transition countries (Ahituv and Kimhi, 2002).

Table 1: Proportion of adult rural population by status and education (\%) and average hourly wages by education (Rwf)

\begin{tabular}{|c|c|c|c|c|c|c|}
\hline & $\begin{array}{c}\text { No } \\
\text { education } \\
\end{array}$ & Primary & $\begin{array}{c}\text { Post- } \\
\text { primary } \\
\end{array}$ & Secondary & $\begin{array}{c}\text { Further } \\
\text { education }\end{array}$ & No. of Obs. \\
\hline \multicolumn{7}{|c|}{ Proportion of adult rural population (\%) } \\
\hline No occupation & 3.7 & 3.6 & 1.9 & 2.3 & 0.0 & \\
\hline Agricultural sector & 88.3 & 77.1 & 58.7 & 21.3 & 0.0 & \\
\hline Non-farm enterprise & 5.5 & 6.7 & 15.0 & 2.4 & 0.0 & \\
\hline Non-farm wage worker & 2.4 & 4.9 & 17.5 & 17.1 & 38.5 & \\
\hline At school & 0.0 & 7.7 & 6.9 & 57.0 & 61.5 & \\
\hline Number of observations & 3965 & 8158 & 361 & 740 & 16 & \\
\hline \multicolumn{7}{|c|}{ Mean Wage for non-farm wage workers (Rwf) } \\
\hline Primary occupation & 52.1 & 78.9 & 159.8 & 193.8 & 646.3 & 1523 \\
\hline Secondary occupation & 75.0 & 107.9 & 272.1 & 217.5 & 2674.7 & 296 \\
\hline \multicolumn{7}{|c|}{ Mean Wage for non-farm self-employed (Rwf) } \\
\hline Primary occupation & 106.8 & 269.1 & 335.7 & 555.1 & 1630.6 & 632 \\
\hline Secondary occupation & 112.8 & 187.8 & 296.4 & 940.6 & 164.8 & 412 \\
\hline
\end{tabular}

Generally, the presence of barriers to entry in specific sectors as well as limited overall economic activity may lead to a concentration of employment in only a few areas. In Rwanda, for instance, wage workers with their primary occupation in the non-farm sector are mostly professionals in public and social services, while those who are self-employed mainly work in commercial and non-agricultural manual occupations. ${ }^{4}$ Consistent with the literature (e.g., Clay et al., 1990), individuals with higher educational levels have greater access to the non-farm sector and derive higher wages (Table 1). In addition,

${ }^{4} 32.5$ percent of non-farm wage workers are professionals and 45.8 percent are in public and para-public. 57.4 percent of non-farm self-employed are in commerce and an additional 32.6 percent are nonagricultural manual workers. 
individuals with higher education (secondary and further education) do not seem to use their skills to engage in self-employment. Rather, they tend to enter the public sector. ${ }^{5}$

Consistent with the notion that wealthier households tend to benefit the most from nonfarm wage employment and self-employment (Reardon, 1997), Table 2 highlights that in Rwanda individuals from wealthier households have greater access to non-farm occupations and receive higher earnings. Moreover, self-employed individuals earn twice as much as people employed in other non-farm activities and in general, at each level of education, non-farm self-employment brings higher money wages.

Richer households are also more likely to have non-farm earnings as their main source of income while for poorer households, agriculture remains the main source of earnings. Additionally, households from the top quintile ${ }^{6}$ depend more on non-farm wage employment than on income from non-farm enterprises (see Table A 1 in Annex 1).

Table 2: Proportion of adult rural population (\%) and average hourly wages (Rwf) by status and household quintile

\begin{tabular}{|c|c|c|c|c|c|c|}
\hline & 1st quintile & 2nd quintile & 3rd quintile & 4th quintile & 5th quintile & No. of Obs. \\
\hline \multicolumn{7}{|c|}{ Proportion of adult rural population (\%) } \\
\hline No occupation & 4.4 & 3.7 & 3.7 & 3.0 & 2.6 & \\
\hline Agricultural sector & 82.5 & 82.1 & 78.6 & 73.0 & 64.5 & \\
\hline Non-farm enterprise & 4.2 & 4.1 & 6.1 & 7.6 & 10.4 & \\
\hline Non-farm wage worker & 2.7 & 2.5 & 5.3 & 5.5 & 11.6 & \\
\hline At school & 6.0 & 7.5 & 6.2 & 10.8 & 10.9 & \\
\hline Number of observations & 2713 & 2750 & 2874 & 2880 & 2026 & \\
\hline \multicolumn{7}{|c|}{ Mean Wage for non-farm wage workers (Rwf) } \\
\hline Primary occupation & 72.9 & 76.6 & 79.6 & 105.2 & 171.3 & 1523 \\
\hline Secondary occupation & 110.0 & 43.7 & 77.2 & 102.6 & 278.6 & 296 \\
\hline \multicolumn{7}{|c|}{$\begin{array}{l}\text { Mean Wage for non-farm self-employed } \\
\text { (Rwf) }\end{array}$} \\
\hline Primary occupation & 40.8 & 71.0 & 107.4 & 140.7 & 422.7 & 632 \\
\hline Secondary occupation & 80.8 & 119.1 & 166.7 & 142.3 & 341.8 & 412 \\
\hline
\end{tabular}

In rural areas richer households are also more likely than poorer ones to diversify into non-farm enterprise activities (Table 3). This is consistent with previous findings that households from the upper income strata have higher shares of non-farm income in total income and higher absolute non-farm earnings (Reardon, 1997). Moreover, households that have a non-farm enterprise in addition to their farm own on average higher land areas - 1.08 ha — than those who have only a farm - 0.72 ha.

\footnotetext{
${ }^{5}$ The main occupation for non-farm wage workers with secondary education is as primary school teacher (61.5 percent of rural adults with secondary or further education who hold a non-farm occupation for their main activity are primary school teachers). The small proportion of individuals with further education who hold an occupation are primary and secondary school teachers, or high level civil servants.

${ }^{6}$ Quintiles are based on data regarding consumption. These variables were derived by the Ministry of Finance in their poverty profile (2002). The description is in Annex 2 of the poverty profile. In short, "The lowest quintile contains the poorest 20 percent of people in Rwanda, ranked according to the consumption standard of living measure of their households, the second quintile the next poorest 20 percent and so on until the top quintile which contains the richest 20 percent.” (page XI, Ministry of Finance, 2002).
} 
Table 3: Relative importance of non-farm enterprise and large scale farm by quintile in rural areas

\begin{tabular}{|c|c|c|c|c|c|c|}
\hline Household engaged in & $1^{\text {st }}$ quintile & $2 \mathrm{~d}$ quintile & $3 \mathrm{~d}$ quintile & 4th quintile & $5^{\text {th }}$ quintile & Total \\
\hline only large scale farm* & 82.5 & 88.3 & 84.3 & 81.8 & 76.0 & 82.8 \\
\hline Both non-farm ent. and large scale farm & 7.1 & 7.1 & 10.6 & 14.5 & 18.6 & 11.4 \\
\hline Only non-farm enterprise & 0.5 & 0.7 & 1.08 & 0.5 & 1.1 & 0.8 \\
\hline Neither & 9.8 & 3.9 & 4.0 & 3.1 & 4.4 & 5.0 \\
\hline Number of observations & 1029 & 1069 & 1151 & 1153 & 869 & 5271 \\
\hline
\end{tabular}

As credit availability is likely to be one of the major determinants for the expansion of non-farm activities, this section concludes with some basic information on credit access and illustrates the limited role currently played by credit markets in supporting the expansion of the sector.

The main sources of capital are personal household savings and loans from parents (Table 4). The use of formal credit markets to start up a non-farm enterprise remains limited, and less formal means such as tontines appear marginal. The reliance on family savings may be linked to the weakening of social interactions in the Rwandan community, especially since the genocide of 1994. Colletta and Cullen (2000), for example, describe a social dynamic in the country whereby individuals cooperate because of shared needs (for example, widows' and orphans' associations), rather than trust.

Table 4: Use of credit in the creation of non-farm enterprises

\begin{tabular}{lcc|cc}
\hline & \multicolumn{3}{c|}{ All areas } & \multicolumn{2}{c}{ Rural areas } \\
\hline & $1^{\text {st }}$ enterprise & $2 \mathrm{~d}$ enterprise & $1^{\text {st }}$ enterprise & $2 \mathrm{~d}$ enterprise \\
\hline Household savings & 64.0 & 74.7 & 63.2 & 75.4 \\
Bank loan & 0.7 & - & 0.6 & - \\
Loan from parents & 12.0 & 6.8 & 10.7 & 5.3 \\
Loan Banque populaire & 0.4 & - & 0.3 & - \\
Other loans & 2.5 & 0.5 & 3.0 & - \\
Tontine & 2.3 & - & 2.2 & - \\
Other & 18.1 & 18.0 & 20.0 & 19.3 \\
& & & & 693 \\
Number of observations & 1124 & 125 & & 65 \\
\hline
\end{tabular}

Among households that start an enterprise, few apply for credit and more than half of those who do are unsuccessful. For those who succeed, the two main sources are "Banques populaires" and other financial institutions (other than private banks). More than 40 percent of enterprises do not have any specific assets ${ }^{7}$, and thus require very limited, if any, start-up capital. Complementary evidence confirms that those enterprises tend to belong to poorer households with no personal wealth. ${ }^{8}$

\footnotetext{
${ }^{7}$ Assets include the following: building, land, machinery, other equipment, bicycles/motorcycles, carts, vehicles, boats, other assets.

${ }^{8} 43$ percent (69 percent) of first enterprises which are started by rural households from the first quintile (fifth quintile) have assets.
} 
Other types of household credit demonstrate a similar pattern: few households take out a loan and these belong mainly to the richer social stratum. Around 33 percent of rural households report owing money or goods to another person, institution or business. ${ }^{9}$ Only a minority of loans originates from formal credit institutions ${ }^{10}$ and is used for business expansion; further, only households from the top quintile appear likely to have access to such forms of credit and use loans for business expansion (Table 5).

Table 5: Proportion of loans taken by household quintile (\%)

\begin{tabular}{lcc|cc}
\hline & \multicolumn{2}{c|}{ Loans with formal credit institutions } & \multicolumn{2}{c}{ Loans for business expansion } \\
\hline & All areas & Rural areas & All areas & Rural areas \\
\hline 1st quintile & 10.0 & 10.1 & 2.2 & 2.3 \\
2d quintile & 13.3 & 13.3 & 2.3 & 2.1 \\
3d quintile & 15.2 & 15.4 & 2.0 & 2.1 \\
$4^{\text {th }}$ quintile & 14.9 & 14.8 & 5.6 & 5.5 \\
$5^{\text {th }}$ quintile & 28.1 & 22.1 & 9.8 & 5.8 \\
& & & & \\
Total & 16.9 & 15.0 & 4.7 & 3.5 \\
\hline
\end{tabular}

\section{Empirical strategy}

\section{Determinants of participation in the non-farm sector}

In the first part of the empirical analysis, we are interested in identifying the factors which influence the decision to participate in the non-farm sector. An individual's decision to participate in the non-farm sector is a function of his productive assets (ability, skills and motivation, the financial and structural status of his household), and the array of opportunities available in the environment in which they live.

In rural areas, individuals enter the non-farm sector until the utility from working in the non-farm sector is equal to that from working in agriculture. In cases where there is an insufficient number of individuals in the non-farm sector, those working in this sector will earn a rent, so that the utility of working in the non-farm sector will be higher than that of working in the agricultural sector. Furthermore, within the non-farm sector, those holding a more highly "protected" activity will earn a higher rent.

We model the probability that an individual is observed working in the non-farm sector. We initially distinguish between self-employed and employed workers. ${ }^{11}$ Individuals' preference to work in the non-farm sector are not observed; we use a standard probit to model the latent variable $\left(y_{i}^{*}\right)$ that represents these preferences:

\footnotetext{
${ }^{9}$ Including loans already reported for non-farm enterprises.

${ }^{10}$ Those are: state banks, private banks, rural credit, agricultural associations, cooperatives, NGOs, enterprises and others

${ }^{11}$ For this, we rely on the answers provided by respondents to direct questions concerning their employment status.
} 


$$
y_{i}^{*}=\beta^{\prime} x_{i}+u_{i}
$$

where $x_{i}$ is the vector of explanatory variables, and $u_{i}$ is the error term, assumed to follow a standard normal distribution with mean zero and variance 1 . In practice we only observe whether an individual works in the non-farm sector or not, we call $y$ the variable which indicates whether individuals participate in non-farm wage employment or not (or whether they participate in non-farm self-employment or not).

$$
\begin{aligned}
& y=1 \text { if } y_{i}^{*}>0 \\
& y=0 \text { otherwise }
\end{aligned}
$$

The probability that an individual participates is: $\operatorname{Prob}\left(y_{i}=1\right)=1-\mathrm{F}\left(-\beta^{\prime} x_{i}\right)$ where $\mathrm{F}$ is the cumulative Normal distribution function.

Based on the analysis of previous empirical and theoretical studies (including Woldenhanna and Oskam, (2001); Reardon (1997); Lanjouw et al. (2001)) and in the context of Rwanda, there are four sets of explanatory variables.

The first set includes individual characteristics. These are the following: educational attainment, age, gender, migration history, parents' education, parents' occupation, presence of parents in household, and household member status. These characteristics constitute the personal assets of individuals; they influence the quality of jobs that they can or expect to get. The quality of a job is determined primarily by the wage and responsibilities offered and therefore the social status of individuals. Specifically, educational attainment, age and migration history represent the skills that individuals have gained. Parental variables indicate both inherited ability and social networks. Household member status gives an indication of the role of individuals in their household, in particular whether they may be considered as the main breadwinner.

The second set includes household level characteristics: number of dependents (14 and younger) divided by total number of household members, land holdings, and livestock. The latter two variables are measured one year before the interview. The former two variables are linked to the family responsibilities of individuals; for example, in two-adult households, both adults can participate in the labor market without facing additional constraints due to having to care for other family members. In Rwanda, mono-parental, female-headed households represent a significant proportion of households and a group "at risk" of greater poverty.

We include a set of dummy variables for the province. In the context of Rwanda, provinces have been affected differently from the various waves of refugees and migrants. We therefore account for that and potentially other provincial characteristics.

Finally we control for community level variables. We do not have any direct information regarding the social capital available in the community, such as that suggested in Lanjouw et al. (2001). We only have what we consider to be indirect evidence of this: net 
migration in the community, presence of a road, degree of accessibility of the road, electricity supply, presence of a market in the community, presence of a primary school, presence of health clinic, presence of agricultural extension service, and presence of farmer association. These community variables are indicative of the level of outside opportunities available to individuals.

We adopt a sequential approach: starting from a basic specification which includes only individual personal characteristics, each group of explanatory variables is added one after the other in the above order. Statistically insignificant variables are dropped and groups of dummies are kept if at least one of the group is significant. The aim of this approach is to reach the specification which has the best fit. ${ }^{12}$

The lack of credit market that has been identified in section 3 has several implications for individuals' participation and income in the non-farm sector. In particular, in a country where there is a lack of credit, individuals belonging to wealthier households will have a greater probability of starting up enterprises that require initial capital investment compared to their counterparts in poorer households. In an econometric model, controlling for all the other characteristics of the individual and his or her household as well as the external environment, individuals with larger wealth will have easier access to the non-farm sector (Reardon, 1997).

In addition to the evidence that the above econometric model will bring, this section provides a more detailed analysis of the extent of the issue of credit constraint. For this purpose, it distinguishes further between the different types of employment within the non-farm sector: non-farm wage employment, non-farm enterprise without assets and non-farm enterprise with assets.

\section{Comparing the outcomes of participants and non-participants}

Our aim is to explain the differences in outcomes, in our case earnings, between individuals who participate in the non-farm sector and those who do not. ${ }^{13}$ However, since the assignment of individuals into non-farm and farm sectors may not be random, the measured return to participating in the non-farm sector may be biased.

This well-known evaluation problem can happen in two ways. First, we do not observe pre-participation earnings of the participants. If both pre- and post-entry earnings were observable, the benefits of non-farm employment for each individual who participates can be determined by averaging the difference of the pre- and post-entry earnings.

Second, missing data also arise because of self-selection. Because those who participate may be very different from those who do not, a simple difference between participants and non-participants will be a biased estimate of returns to non-farm participation. In principle, if factors that select some workers into non-farm sector, such as ability were observable, then they can be taken into account to obtain a true estimate of the return to non-farm sector. However, these data are rarely available.

\footnotetext{
${ }^{12}$ Results are analyzed in section 5 . We present only results for our preferred specification but detailed results are available from the authors upon request.

${ }^{13}$ This section explains the methods in the case of individual level data. These explanations hold for the analysis at the household level that we also carry out below.
} 
We use the propensity score matching method to address this issue (Rosenbaum and Rubin, 1983). The idea is to create groups of participants and non-participants who are as similar as possible and then use the differences in their outcome (that is earnings) in order to obtain a credible estimate of the benefits of non-farm participation (see for example an application in Levine and Painter, 2003). Specifically, suppose the earnings of a participant are $Y_{i 1}$, and the pre-entry earnings of the same individual are $Y_{i 0}$, where $i$ indexes the population of interest, and $T_{i}=\{1,0\}$ denotes participation status. Then the benefit of participation is,

$$
\Delta_{i}=Y_{i 1}-Y_{i 0}
$$

However, while the first of the terms on the right is observable, the second, $Y_{i 0}$, is not. One of our key goals is therefore to try and obtain an estimate of this missing data. As a starting point, we have to accept the impossibility of obtaining $\Delta_{i}$, the benefit of participation for any participant, and focus instead on the average benefit in the population (Heckman, LaLonde and Smith, 1999). This makes it possible to estimate the last term of equation (1) from the sub-sample of non-participants (the untreated) in the population, and thereby obtain an estimate of the average benefit of participating. That is,

$$
\Delta^{e}=E\left(Y_{i 1} \mid T_{i}=1\right)-E\left(Y_{i 0} \mid T_{i}=0\right)
$$

While this difference can be estimated, it is potentially biased if participants and nonparticipants differ significantly in their characteristics, and we use the earnings of the non-participants to estimate the pre-entry earnings of the participants (Dehejia and Wahba, 1999).

We can minimize this bias by obtaining the same observable characteristics (covariates) from participants and non-participants and then match each participant with a nonparticipant on the sameness/similarity of these covariates. Effectively, this implies assigning observations into cells defined by unique values of the covariates.

If the number of characteristics used for matching is small, then it is easy to create the necessary comparable groups. For instance, with two binary variables, there would be four groups (cells). However, matching on the covariates can be daunting if they are multi-dimensional and one or more take continuous values. Therefore, a key argument for focusing on the propensity score matching is to reduce this high dimensionality.

First we estimate the probability of participating in the non-farm sector conditional on the pre-treatment characteristics, $X$, in order to obtain a single-index variable (the propensity score) to make the matching feasible. That is,

$$
\operatorname{Pr}\left(T_{i}=1 \mid X_{i}\right)=E\left(T_{i} \mid X_{i}\right)=p\left(X_{i}\right)
$$


The propensity score matching methods use observable characteristics to reduce the bias that is attributable to unobservable factors. The extent to which the bias is reduced depends on the quality of the conditioning variables (Becker and Ichino, 2002). We believe that the diversity of variables we have chosen accomplishes this objective and that the assumption that, conditional on the observable factors, participation in the nonfarm sector is not correlated with unobservable that predict future earnings is satisfied. Our observable characteristics include a rich set of individual, household, community and provincial level characteristics (see Annex 3). Individuals' characteristics control for personal differences in endowments and skills, while parental education and experience in the non-farm sector control for possible differences in values and preferences that are passed on across generations. Household level characteristics are a proxy for household wealth, which is likely to influence individuals' decision to participate in the non-farm sector. We also include community level variables to take account of differences in economic opportunities available to individuals living in disparate communities. We add provincial level dummies to control for natural, political, and economic differences across provinces. ${ }^{14}$

We consider that working age individuals can choose among six mutually exclusive alternatives; these consist of five occupational choices as well as a "no occupation" option (see section 5.2). Our interest is in the causal average effect of a choice relative to another choice on some outcome (e.g. earnings). We calculate propensity scores using a standard probit (similar to the one described above) where the binary dependent variable represents the two alternatives that we want to compare.

Next we match participants and non-participants with the same or similar propensity score $^{15}$ (see Sianesi (2001) or Becker and Ichino (2002) for more details on the assumptions behind the estimation). We use several matching methods. ${ }^{16}$ In the first, the nearest matching estimators with replacement, we compare a participant and a non-participant whose propensity scores are sufficiently close, by recognizing that it is impossible to obtain exact propensity scores for all pairings of participating and non-participating individuals, and that a non-participating individual can be a best match for more than one participating individual. In the second, we try kernel matching. Rather than match one participant with one non-participant, we can use several non-participants, to act as the matches for a participant. The idea is to calculate the average propensity score from a neighborhood of propensity scores of several comparison members (nonparticipants), match this average propensity score to the propensity score of a participant and then proceed to obtain the average participation effect as in equation (2). We use

\footnotetext{
14 This specification is consistent with previous empirical literature (see Woldenhanna and Oskam, 2001; Reardon, 1997; and Lanjouw et al., 2001).

${ }^{15}$ We have used the Stata program developed by Sianesi (2001). In order to check the robustness of the results, we also used the programs created by Becker and Ichino (2002), the results (not shown) were similar.

${ }^{16}$ More technical and detailed presentation of these estimators can be found in Becker and Ichino (2002).
} 
kernel, specifically, Gaussian for this step but report results from another kernel method, Epanechnikov, to test the robustness of the results. ${ }^{17}$

Finally, we take the difference in earnings between the matched participants and nonparticipants, and sum over all the differences to obtain the $\Delta^{e}$ as in equation (2).

\section{Results and discussion}

\subsection{The determinants of participation in the non-farm sector}

Before focusing on comparing outcomes of participation in the non-farm sector, it is interesting to identify the main determinants of participation into non-farm self-employment and wage employment.

The econometric analysis confirms that education is a significant determinant of participation in the non-farm sector, in particular in non-farm wage employment. For both men and women, higher levels of education are positively associated with higher probability of participating in the non-farm sector (Figure 1). We find that having some education is associated with a greater chance of participating in self-employment for men, while only post-primary education matters for women's participation. Education is even more strongly correlated with participation in wage employment for both men and women. This correlation increases with education level with the strongest effect coming from having secondary or further education (Table 10 and Table 11). When we look at the two types of self-employment (columns 3 and 4 in Table 10 and in Table 11), we see that education is more strongly correlated with participating in self-employment in an enterprise with assets. This is consistent with the idea that such activities are more complex and often specific skills. For women, education does not even enter as a determinant of participation in non-farm self-employment without assets, indicating that these activities are probably low-level occupations.

We also find that lack of household wealth is not an impediment to entering non-farm wage employment (column 2 in Table 10 and in Table 11). There is no difference in the probability of non-farm wage employment between men and women from wealthy households on the one hand - defined as those with average land and livestock holding of the top $20 \%$ in land and livestock holding - and the men and women from poorer households on the other hand. Wealth, as defined here, also matters little in the likelihood of self-employment among women (column 1 in Table 11). It does matter among men, but only consistently for enterprises which have assets, which offers partial support to the presence of credit constraints in the economy (column 1, 3 and 4 in Table 10). It seems that individuals from richer households can afford to bear the risk involved in self-employment, thanks to the capital available from the family.

\footnotetext{
${ }^{17}$ We have used the Stata program developed by Sianesi (2001). In order to check the robustness of the results, we also used the programs created by Becker and Ichino (2002), the results (not shown) were similar.
} 
Figure 1: Average predicted probabilities by educational level (all other characteristics at their actual value)

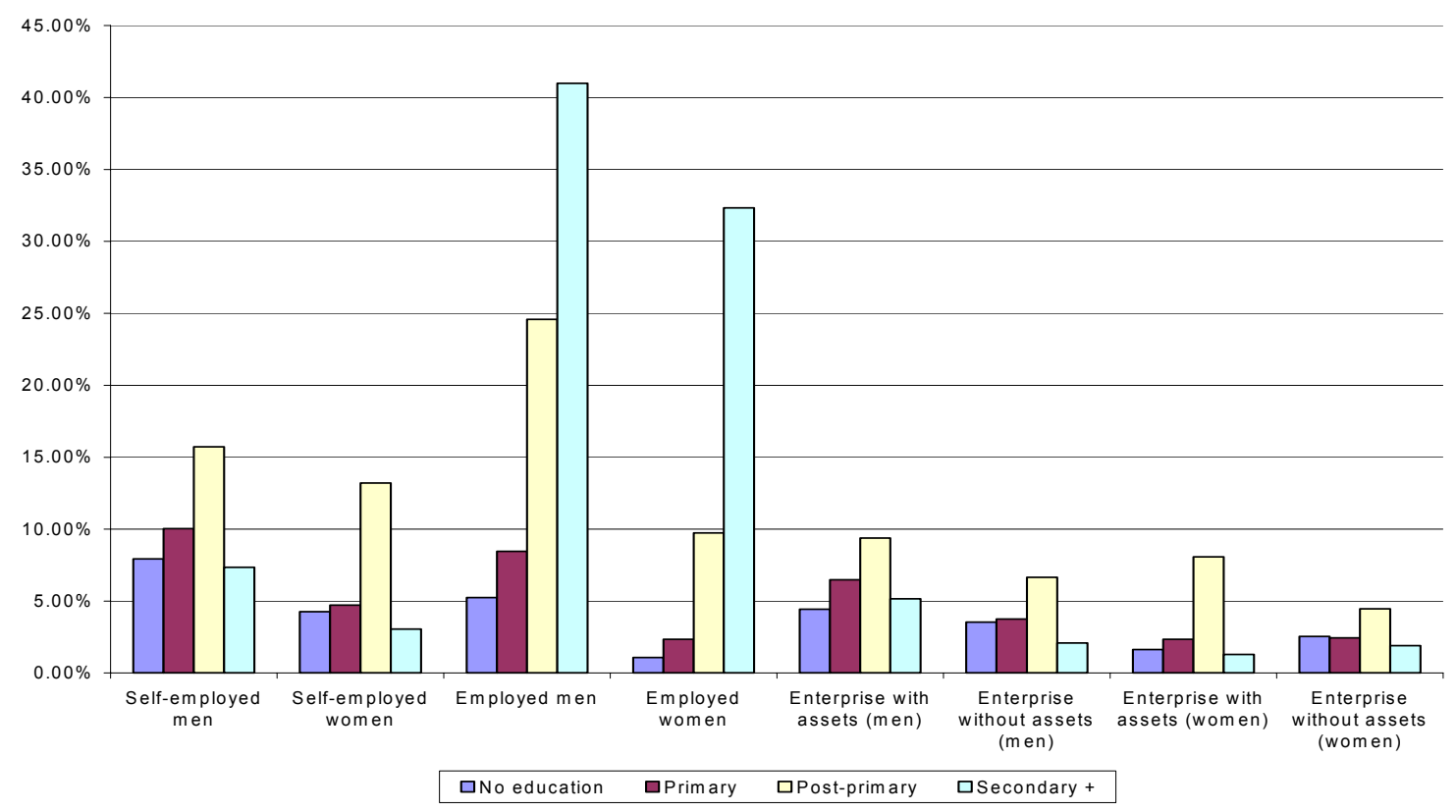

Turning to the effects of community infrastructure, we find that the presence of a primary school further away from the community is associated with lower chances of participating in non-farm self-employment, especially self-employment with assets. It does not affect participation in non-farm wage employment. Other infrastructures enter with the expected effects; lower level of infrastructures and community-level activities are associated with lower participation in non-farm wage employment and selfemployment. We can note in particular that access to road and markets is particularly important for women's participation in non-farm self-employment with assets.

Finally, we looked at the role of family background on participation in the non-farm sector. This matters because parents may bring their relations and network to the help of their children, so that their children have easier access to non-farm wage employment or self-employment. At the same time, non-farm employed parents may transmit the specific skills of their trade to their children. Therefore, parents who participate in the non-farm sector can ease access to the sector for their children. Our results show that the probability that men become self-employed in the non-farm sector increases by about 3 percentage points if their father reached primary education, and by nearly 4 percentage points if he had or currently has an occupation in the non-farm sector (column 1 in Table 10). We find also that the probability of non-farm wage employment is much higher for men and women whose mother is involved in the non-farm sector, which is consistent with the hypothesis that mothers are the key agents for transmitting family values and preferences (column 2 in Table 10 and in Table 11). These results are consistent with previous literature on the link between parents' achievements and the likelihood that their children will become self-employed (Dunn and Holtz-Eakin, 2000). Dunn and Holtz-Eakin find that the parental effect occurs through their self-employment experience and business success. 


\subsection{Outcome differences between farm and non-farm sectors}

\section{Comparing individuals' outcomes}

Having looked at the determinants of the probability of participating in different activities in rural Rwanda, we now examine the size of earnings differentials. In rural areas of Rwanda, individuals" "basic" activity is farming on the family farm. Then the choice of most individuals is whether to farm only, or to farm and do some off-farm activity at the same time. These off-farm activities are the following: agricultural worker, non-farm wage worker and non-farm self-employed. This leads us to define six outcomes (See Annex 2 for a detailed description of occupational choices):

1. Farmer only

2. Agricultural worker (may also work on family farm)

3. Non-farm wage worker (may also work on family farm)

4. Non-farm self-employed (may also work on family farm)

5. Other combinations of main and secondary occupations

6. No occupation

As we are specifically interested in the non-farm sector, we carry out the following pair wise comparisons (3) versus (2), (4) versus (2) and (4) versus (3). For each pair, we compare the observed hourly payment received. We then split the sample into two sub samples: the poor (individuals from households belonging to the first and second quintiles) and the non-poor (individuals from households belonging to the three upper quintiles), and we do the same comparisons. This split enables us to see the extent to which the choices made by the poor are the product of constraints different to that of the non-poor.

Outcome (4) can be further divided into those who have a firm with assets (specifically used for the enterprise) and those who have a firm with no assets. We identify the latter because the questionnaire indicates to the interviewer to report assets which are used only for the relevant enterprise and not used by the household or by another enterprise. This means however that those who report having "no assets" may be using assets (e.g. building or land) which are also used by the household for other purposes. ${ }^{18}$

We make this distinction because, starting up a firm without assets involves lower financial costs and more generally lower requirement of household and individual skills compared to a firm which has its own specific assets. In order to compare alternatives which attract similarly skilled individuals or households, we make the following two comparisons: (i) self-employed in firms without assets are compared to farm workers; these two alternative require little if any household wealth to be carried out, i.e. they have no start-up costs; (ii) non-farm self-employed in firms with assets are compared to non-

\footnotetext{
${ }^{18}$ Outcomes 5 and 6 represent less than 6 percent of rural adults. In order to have a consistent analysis we
} drop the 0.3 percent of rural adults not belonging to farm households ( 36 observations). 
farm wage workers; individuals who choose one of these two activities are likely to face large start-up/fixed costs to be able to engage in these, household wealth is therefore likely to play a significant role in these choices.

Table 6: Summary of earnings differentials

\begin{tabular}{|c|c|c|c|}
\hline & $\begin{array}{l}\text { Nearest neighbor } \\
\text { matching }\end{array}$ & $\begin{array}{l}\text { Gaussian kernel } \\
\text { matching }\end{array}$ & $\begin{array}{c}\text { Epanechnikov } \\
\text { kernel } \\
\text { matching }\end{array}$ \\
\hline \multicolumn{4}{|l|}{ A. All } \\
\hline Non-farm wage worker $>$ farm worker & 19.8 & $30.1 *$ & $26.7^{*}$ \\
\hline Non-farm self-employed $>$ non-farm wage worker & $139.8 *$ & $139.4 *$ & $137.9 *$ \\
\hline Non-farm self-employed $>$ farm worker & $173.1 *$ & $154.3 *$ & $156.4^{*}$ \\
\hline Non-farm self-employed without assets $>$ farm worker & $115.1 *$ & $121.4 *$ & $121.8 *$ \\
\hline $\begin{array}{l}\text { Non-farm self-employed with assets }>\text { non-farm wage } \\
\text { worker }\end{array}$ & $165.4 *$ & $167.6^{*}$ & $165.2 *$ \\
\hline \multicolumn{4}{|l|}{ B. Poor } \\
\hline Non-farm wage worker $>$ farm worker & 39.3 & 42.6 & 37.8 \\
\hline Non-farm self-employed $>$ non-farm wage worker & $51.3 *$ & 39.7 & 37.0 \\
\hline Non-farm self-employed $>$ farm worker & $63.3 *$ & $63.3 *$ & $61.2 *$ \\
\hline Non-farm self-employed without assets $>$ farm worker & $27.9^{*}$ & $24.6^{*}$ & 21.9 \\
\hline $\begin{array}{l}\text { Non-farm self-employed with assets }>\text { non-farm wage } \\
\text { worker }\end{array}$ & 47.8 & 59.1 & 60.7 \\
\hline \multicolumn{4}{|l|}{ C. Non-poor } \\
\hline Non-farm wage employment $>$ farm worker & 18.8 & $24.7 *$ & $23.2 *$ \\
\hline Non-farm self-employed $>$ non-farm wage worker & $157.2 *$ & $163.5^{*}$ & $159.9 *$ \\
\hline Non-farm self-employed $>$ farm worker & $200.5^{*}$ & $174.4^{*}$ & $178.4^{*}$ \\
\hline Non-farm self-employed without assets $>$ farm worker & $141.8 *$ & $147.0 *$ & $146.9^{*}$ \\
\hline $\begin{array}{l}\text { Non-farm self-employed with assets }>\text { non-farm wage } \\
\text { worker }\end{array}$ & $174.1 *$ & $178.8 *$ & $174.7^{*}$ \\
\hline
\end{tabular}

Notes: A * means that the difference in statistically significant at $5 \%$.

For example the first number in the table can be interpreted in the following way: individuals engaged in non-farm wage employment earn on average 19.8 Rwf more than individuals with similar observed characteristics engaged in farm employment.

Table 6 summarizes the results. There are three main conclusions. First, individuals in non-farm self-employment earn more than farm workers. Farm workers could on average double their salary if they decided to participate in non-farm wage employment This observation holds true for the non-farm self-employed sector as a whole and for self-employed without assets. This finding is robust to whether the data are split into poor and non-poor households or the matching method used. Second, we find that not only do non-farm self-employed earn more than farm workers, but that they earn more than non-farm wage workers. Namely, average non-farm wage workers could multiply their earnings by nearly 2.5 by becoming self-employed, while farm workers by a factor of nearly 6 . However, in this case, the earning differential appears to be mainly due to the high premium earned by the self-employed in firms with assets in non-poor households compared to their non-poor counterparts in non-farm wage employment. This result is a rigorous confirmation of the received wisdom regarding the self-employed 
sector: that those on the lower tail of its skill mix obtain no better measurable returns than the low skill workers in competing sectors (such as agriculture). This may be because at this end of the skill mix, there may be fewer barriers to entry or it could be that the products have low skill content and therefore attract low demand. Finally, we find that the difference in earnings between the self-employed and farm workers or non-farm wage employees is much smaller among the poor than among the non-poor. Since the difference in earnings among the non-poor is higher than the average difference in earnings in the economy, there is a possibility that the self-employed sector may have led to a widening of the earnings differential (inequality) in the economy.

\section{Comparing households' outcomes}

In addition to looking at differences in outcomes between individuals, we looked at differences in outcomes between households. We focused our attention on the differences that stem from diversification of economic activity and participation in the market, two household strategies that are believed to be crucial in determining the wealth of households. To help identify such households we relied on two separate questions posed to the households and not individuals. One question asked whether the household had a non-farm enterprise. Specifically, it sought to establish whether the household as a unit engaged in non-farm activities. The second question asked households with farms whether they sold all or part of their crops in the market in the last 12 months. ${ }^{19}$ Based on these two questions we created four mutually exclusive household statuses to which rural households could belong: (a) farm enterprise, i.e. households that engaged only in farming but sold part or all their produce in the market; (b) non-farm enterprise, i.e. household holding a non-farm enterprise but growing crops for own consumption, (c) farming for own consumption only (autarky); and (d) households with a farm enterprise and a non-farm enterprise.

The comparison of households' outcomes in term of per capita expenditures are shown in Table 7. First, note that households which produce only for own consumption have significantly less consumption than households which have a non-farm enterprise. Second, we find that there is no difference in welfare outcomes, measured as adult equivalent household expenditures, between farm enterprises, that is households who do only farming but participate in the market, and non-farm enterprises. This result differs from the above comparison among individuals because in the latter case, it was difficult to identify individuals who farmed only for own consumption from those who farmed and participated in the market. These two results together suggest that farmers who participate in the market have higher consumption than farmers who produce for own consumption. In short, autarky (not participating in the market) has the potential to impoverish households. Finally, we find that having a farm enterprise and non-farm enterprise is significantly more profitable than having a farm enterprise alone. However, these benefits of market participation are captured only by households in the top $60 \%$ of the consumption distribution. Among the poor, there are no gains to market participation and to owning non-farm enterprises.

\footnotetext{
${ }^{19}$ With this definition, we hope to distinguish between what we call "farm enterprises" and farming for autoconsumption.
} 
Table 7: Outcomes of rural households according to their activities $(\mathbf{R w f})^{20}$

\begin{tabular}{|c|c|c|c|}
\hline & $\begin{array}{c}\text { Nearest neighbor } \\
\text { matching }\end{array}$ & $\begin{array}{c}\text { Gaussian kernel } \\
\text { matching }\end{array}$ & $\begin{array}{c}\text { Epanechnikov } \\
\text { kernel matching }\end{array}$ \\
\hline \multicolumn{4}{|c|}{ A. Deflated expenditure per equivalent adult in household } \\
\hline $\begin{array}{l}\text { Non-farm enterprise (b) minus Farm } \\
\text { enterprise (a) }\end{array}$ & +10932.7 & +5902.8 & +7246.0 \\
\hline $\begin{array}{l}\text { Non-farm enterprise (b) minus } \\
\text { farming for own consumption (c) }\end{array}$ & $+17111.2 *$ & $+17863.6^{*}$ & $+17833.2 *$ \\
\hline $\begin{array}{l}\text { Non-farm and farm enterprises (d) } \\
\text { minus Farm enterprise (a) }\end{array}$ & $+26469.1^{*}$ & $+21398.6^{*}$ & $+19891.4^{*}$ \\
\hline \multicolumn{4}{|c|}{ A. POOR } \\
\hline \multicolumn{4}{|c|}{ Deflated expenditure per equivalent adult in household } \\
\hline $\begin{array}{l}\text { Non-farm enterprise (b) minus Farm } \\
\text { enterprise (a) }\end{array}$ & $-2860.3^{*}$ & -1238.7 & -1296.4 \\
\hline $\begin{array}{l}\text { Non-farm enterprise (b) minus } \\
\text { farming for own consumption (c) }\end{array}$ & +432.6 & +1764.7 & +1665.2 \\
\hline $\begin{array}{l}\text { Non-farm and farm enterprises (d) } \\
\text { minus Farm enterprise (a) }\end{array}$ & +199.6 & +177.9 & +182.2 \\
\hline \multicolumn{4}{|c|}{ B. NON-POOR } \\
\hline \multicolumn{4}{|c|}{ Deflated expenditure per equivalent adult in household } \\
\hline $\begin{array}{l}\text { Non-farm enterprise (b) minus Farm } \\
\text { enterprise (a) }\end{array}$ & $+19751.9^{*}$ & +11784.8 & +13234.6 \\
\hline $\begin{array}{l}\text { Non-farm enterprise (b) minus } \\
\text { farming for own consumption (c) }\end{array}$ & +16209.2 & +12741.8 & +13305.8 \\
\hline $\begin{array}{l}\text { Non-farm and farm enterprises (d) } \\
\text { minus Farm enterprise (a) }\end{array}$ & $+20906.9^{*}$ & $+15218.6^{*}$ & $+14310.7^{*}$ \\
\hline
\end{tabular}

Notes: the letters in parentheses refer to the outcomes explained in text.

$*$ refers to a statistically significant result at 5\%.

Expenditures were deflated with the price index and divided by the number of equivalent adults developed in the Poverty Profile (2002).

The results presented can be interpreted in the following way: 10932.7 is the level of deflated expenditure per adult equivalent for rural households with a non-farm enterprise minus the level of expenditure for similar households which have a farm enterprise (i.e. which sold some of their harvest on the market).

It is now generally established that households diversify their economic activities in order to mitigate or reduce income variance in a risky environment. While this insures against a really bad outcome (in case a household relied on just one risky activity), it also, potentially, excludes the household from engaging in high return activities that come from specialization. We compared the poverty outcomes (using expenditure per adult equivalent) of households which are only in farming and comparable farm households with non-farm enterprises, or more diversified households. The results show that rural households which participate in non-farm self-employment are on average less poor than those which are only in farming. On average the diversified households belong to the fourth quintile of consumption distribution, while the non-diversified households belong to the third quintile.

\section{Does agricultural risk explain households choices?}

We now explore more rigorously, the idea that diversification into non-farm enterprises is motivated by mitigation or reduction of the potentially high output risk in agriculture.

\footnotetext{
${ }^{20}$ In order to take into account the saving behavior of Rwandese (even though the great majority have no savings), we did the same analysis with the sum of expenditures and net savings in the previous 12 months and found similar results.
} 
We measure the risks that households face in agriculture through the predicted probability that farm households have zero or negative profits ${ }^{21}$ from their agricultural activities. We compare this outcome across comparable groups of diversified and non-diversified households.

To be specific, we offer a brief explanation of the procedure. In step one we obtained the probability of being diversified - the propensity score, (e.g., being in the farm and non-farm sectors compared to being only in the farm sector). Next, we matched diversified and non-diversified households on the propensity score. Having obtained groups of comparable households, we calculate the average difference in the predicted probabilities of having a negative or zero profit from farming across the diversified and non-diversified households. These predicted probabilities are obtained through a probit model where having zero or negative profits from farming is a function of sets of variables which normally influence farming profits (human capital in the household, crops specialization, use of modern agricultural techniques, access to markets and other amenities, agricultural land and livestock and use of modern credit facilities). ${ }^{22}$

Table 8 shows that for any pair wise comparison of diversified and non-diversified households, the former do not seem to be different in terms of predicted probability of farm losses compared to non-diversified households (see panel A). The difference between diversified and non-diversified households is found to be statistically insignificant or, when found significant, is very small; while the predicted probability of having zero or negative profit is of the order of 2 percent, the difference is of the order of 0.6 percentage points. The results hold across the entire distribution of farm households, that is whether they are at the top end of wealth distribution or at the bottom (panels B and C). The only statistically significant result holds for poor and non-poor households. It shows that farm households which chose to have a non-farm enterprise rather than sell their farm production on the market have a slightly higher risk of having zero or negative profit from farming.

\footnotetext{
${ }^{21}$ Farm profits are calculated as net income from farming (see Annex 2). Net income is obtained even for households which do not sell on the market by applying to their farm production the average prices faced by households in the same Prefecture.

${ }^{22}$ The variables are the following: (i) human capital (head's level of schooling, head's age), (ii) crops specialization (number of piecemeal crops, number of large crops, type of crops (cereals, tubers, vegetables, tea/coffee, fruits, and sugar/tobacco)), (iii) use of modern agricultural techniques (fertilizer, irrigation and/or insecticides and/or herbicides), (iv) access to amenities (presence of farmers association, presence of agricultural extension), (v) use of modern credit facilities (used a loan from a formal credit institution), (vi) agricultural land and livestock.
} 
Table 8: Difference in agricultural risk by household activity

\begin{tabular}{|c|c|c|c|}
\hline & $\begin{array}{c}\text { Nearest } \\
\text { neighbor } \\
\text { matching } \\
\text { methodology }\end{array}$ & $\begin{array}{l}\text { Gaussian } \\
\text { kernel } \\
\text { matching }\end{array}$ & $\begin{array}{c}\text { Epanechnikov } \\
\text { kernel } \\
\text { matching }\end{array}$ \\
\hline \multicolumn{4}{|l|}{$\begin{array}{l}\text { A. ALL } \\
\text { Difference in the predicted probability of } \\
\text { having zero or negative farm profits }\end{array}$} \\
\hline $\begin{array}{l}\text { Non-farm enterprises (b) minus Farm } \\
\text { enterprise (a) }\end{array}$ & 0.007 & $0.008^{*}$ & $0.006^{*}$ \\
\hline $\begin{array}{l}\text { Non-farm enterprise (b) minus farming for } \\
\text { autoconsumption (c) }\end{array}$ & -0.0006 & -0.003 & -0.001 \\
\hline $\begin{array}{l}\text { Non-farm and farm enterprises (d) minus } \\
\text { Farm enterprise (a) }\end{array}$ & -0.0006 & -0.0001 & -0.0003 \\
\hline \multicolumn{4}{|l|}{$\begin{array}{l}\text { B. POOR } \\
\text { Difference in the predicted probability of } \\
\text { having zero or negative farm profits }\end{array}$} \\
\hline $\begin{array}{l}\text { Non-farm enterprises (b) minus Farm } \\
\text { enterprise (a) }\end{array}$ & 0.008 & $0.015^{*}$ & $0.009^{*}$ \\
\hline $\begin{array}{l}\text { Non-farm enterprise (b) minus farming for } \\
\text { own consumption (c) }\end{array}$ & -0.001 & 0.001 & 0.001 \\
\hline $\begin{array}{l}\text { Non-farm and farm enterprises (d) minus } \\
\text { Farm enterprise (a) }\end{array}$ & 0.008 & 0.0009 & 0.0005 \\
\hline \multicolumn{4}{|l|}{$\begin{array}{l}\text { C. NON-POOR } \\
\text { Difference in the predicted probability of } \\
\text { having zero or negative farm profits }\end{array}$} \\
\hline $\begin{array}{l}\text { Non-farm enterprises (b) minus Farm } \\
\text { enterprise (a) }\end{array}$ & 0.007 & & $0.006^{*}$ \\
\hline $\begin{array}{l}\text { Non-farm enterprise (b) minus farming for } \\
\text { own consumption (c) }\end{array}$ & -0.004 & & -0.002 \\
\hline $\begin{array}{l}\text { Non-farm and farm enterprises (d) minus } \\
\text { Farm enterprise (a) }\end{array}$ & -0.003 & & -0.0003 \\
\hline
\end{tabular}

We also looked at actual difference in profits between the matched pairs. Table 9 indicates the average of the pair wise differences for poor and non-poor households. The results confirm the general conclusions of Table 8 . When comparing households with similar characteristics, farm profits between diversified and non-diversified households are not significantly different, except between farm households which sell on the market and those which do not sell on the market but have a non-farm enterprise. Our results in Table 8 and Table 9 suggest that households in Rwanda are not driven into non-farm enterprises by risks in farm output. This is not to suggest that risk is not a motivation for diversification. Even in this context, the fact that we do not observe significant differences in risk as measured through variations in actual or expected profits does not preclude risk differences which we are not able to measure directly. That said, we do not find empirical evidence to suggest that the farm households who diversify into non-farm enterprises are particularly more prone to volatile agricultural income. Overall, it appears that the decision to participate in the non-farm sector is unrelated to profits in the farming activity of the household. This is consistent with previous findings that risk mitigation do not satisfactorily explain participation in the non-farm sector in rural Africa (Barrett et al, 2001). 
Table 9: Differences in the level of farming profits of rural households according to their activities (Rwf)

\begin{tabular}{|c|c|c|c|}
\hline & $\begin{array}{l}\text { Nearest neighbor } \\
\text { matching }\end{array}$ & $\begin{array}{l}\text { Gaussian kernel } \\
\text { matching }\end{array}$ & $\begin{array}{l}\text { Epanechnikov } \\
\text { kernel matching }\end{array}$ \\
\hline \multicolumn{4}{|l|}{ A. POOR } \\
\hline $\begin{array}{l}\text { Non-farm enterprises (b) minus Farm } \\
\text { enterprise (a) }\end{array}$ & $-12765.6(-24 \%)$ & $-13470.7 *(-25 \%)$ & $-14462.4 *(-26 \%)$ \\
\hline $\begin{array}{l}\text { Non-farm enterprise (b) minus farming for } \\
\text { own consumption (c) }\end{array}$ & $-171.4(-0.4 \%)$ & $+3912.4(10.6 \%)$ & $+2978.7(7.9 \%)$ \\
\hline $\begin{array}{l}\text { Non-farm and farm enterprises (d) minus } \\
\text { Farm enterprise (a) }\end{array}$ & $-4530.4(-7.4 \%)$ & $+1276.4(2.3 \%)$ & $-304.4(-0.5 \%)$ \\
\hline \multicolumn{4}{|l|}{ B. NON-POOR } \\
\hline $\begin{array}{l}\text { Non-farm enterprises (b) minus Farm } \\
\text { enterprise (a) }\end{array}$ & $-26945.0 *(-32.6 \%)$ & $-15863.7 *(-22.2 \%)$ & $-15851.9 *(-22 \%)$ \\
\hline $\begin{array}{l}\text { Non-farm enterprise (b) minus farming for } \\
\text { own consumption (c) }\end{array}$ & $-2770.0(-4.7 \%)$ & $+4426.3(8.6 \%)$ & $+2740.5(5.1 \%)$ \\
\hline $\begin{array}{l}\text { Non-farm and farm enterprises (d) minus } \\
\text { Farm enterprise (a) }\end{array}$ & $+2844.1(3.9 \%)$ & $+831.2(1.1 \%)$ & $+876.4(1.2 \%)$ \\
\hline
\end{tabular}

\section{Conclusion}

In many developing countries, outcomes (earnings, wages, expenditures, etc.) in the rural non-farm sector are often found to be higher than the same outcomes for rural farmers, but the differences cannot be explained by education and skill level differences alone (Reardon, 1997; Clay et. Al, 1995). It is possible that the differences stem from looking at inappropriate comparison groups. For rural Rwanda, we have sought to reduce this problem, and produce credible results, by using the propensity score matching methods, where we created appropriate comparison groups of individuals and households.

Our analysis leads to several interesting results. First we find that non-farm selfemployed individuals in rural Rwanda have significantly higher earnings than farm workers and non-farm formal employees. Second, we show that the benefits to non-farm self-employment are much higher among the non-poor than among the poor. Third, we show that diversified households, those with a farm and a non-farm enterprise, are less likely to be poor. The average diversified household is one quintile higher $\left(4^{\text {th }}\right.$ quintile in consumption distribution) than the average non-diversified household ( $3^{\text {rd }}$ consumption quintile). Moreover, we do not find that households that diversify are proportionately more risk-prone in the sense that their farm profits are more volatile. Fourth, farm households who do not participate in the market have significantly much lower consumption levels than households that do. However, the benefits to market participation appear to matter less for the poor than for the non-poor. In this paper we find little difference in expenditures between market participants and non-market participants, for comparable households in the bottom $40 \%$ of the expenditure distribution. 
We have found in our descriptive analysis that Rwanda's rural non-farm self-employment sector is smaller now than it was in the early 1990s and compared to neighboring African countries. At present the main beneficiaries of participating in the sector appear to be non-poor individuals and households. The earnings differential for the self-employed among the non-poor are higher than the economy-wide average differential and the differential among the poor. This has the potential to increase inequality in earnings. Yet, the key message from the foregoing analyses is that this sector holds great promise in improving household earnings and expenditures, and in the end poverty reduction. The main objective of future policy should focus on facilitating its expansion, finding ways to include the poor, and increasing their earnings. This will be the subject of future work. We plan to undertake policy simulations in detail to explore the impact of expanding the non-farm sector on poverty reduction. In addition, we plan to develop more robust measures of earnings variability in order to better understand the link between income risk and occupational choice. 
Table 10: Participation in the non-farm sector for rural men (Marginal effects in percentage points)

\begin{tabular}{|c|c|c|c|c|}
\hline & $\begin{array}{c}\text { Self- } \\
\text { employment }\end{array}$ & $\begin{array}{c}\text { Wage } \\
\text { employment }\end{array}$ & $\begin{array}{l}\text { Non-farm } \\
\text { enterprise } \\
\text { with assets }\end{array}$ & $\begin{array}{c}\text { Non-farm } \\
\text { enterprise } \\
\text { without asset }\end{array}$ \\
\hline \multicolumn{5}{|l|}{ Personal characteristics } \\
\hline \multicolumn{5}{|l|}{ No education } \\
\hline \multirow[t]{2}{*}{ Primary } & $1.94 * *$ & $3.34 * *$ & $1.74^{* *}$ & 0.19 \\
\hline & $(0.01)$ & $(0.01)$ & $(0.01)$ & $(0.01)$ \\
\hline \multirow[t]{2}{*}{ Post-primary } & $8.25^{* *}$ & $24.20 * *$ & $5.33 * *$ & $2.84 *$ \\
\hline & $(0.03)$ & $(0.05)$ & $(0.03)$ & $(0.02)$ \\
\hline \multirow[t]{2}{*}{ Secondary +} & -0.60 & $42.32 * *$ & 0.77 & -1.31 \\
\hline & $(0.02)$ & $(0.04)$ & $(0.02)$ & $(0.01)$ \\
\hline \multirow[t]{2}{*}{ Age } & $-0.12 * *$ & $-0.12 * *$ & $-0.07 * *$ & -0.03 \\
\hline & $(0.0004)$ & $(0.0004)$ & $(0.0003)$ & $(0.0002)$ \\
\hline \multicolumn{5}{|l|}{ Head of household } \\
\hline Spouse & $\begin{array}{c}2.88 \\
(0.11)\end{array}$ & - & $\begin{array}{c}5.31 \\
(0.10)\end{array}$ & \\
\hline \multirow[t]{2}{*}{ Close family } & $-10.18^{* *}$ & -2.46 & $-6.61 * *$ & $-3.03 * *$ \\
\hline & $(0.01)$ & $(0.02)$ & $(0.01)$ & $(0.01)$ \\
\hline \multirow[t]{2}{*}{ Other relatives } & $-6.93 * *$ & -2.39 & $-3.76^{* *}$ & $-2.89 * *$ \\
\hline & $(0.01)$ & $(0.02)$ & $(0.005)$ & $(0.004)$ \\
\hline \multirow[t]{2}{*}{ Domestic \& other } & $-7.92 * *$ & $5.27 * *$ & $-4.48 * *$ & \\
\hline & $(0.005)$ & $(0.03)$ & $(0.004)$ & \\
\hline \multirow[t]{2}{*}{ Time since last move } & $-0.11 * *$ & $-0.10^{* *}$ & -0.05 & -0.07 \\
\hline & $(0.001)$ & $(0.001)$ & $(0.0004)$ & $(0.0004)$ \\
\hline \multicolumn{5}{|l|}{ Father's characteristics } \\
\hline \multicolumn{5}{|l|}{ No education } \\
\hline \multirow[t]{2}{*}{ Primary } & $2.86^{* *}$ & 0.03 & $2.22 * *$ & 0.51 \\
\hline & $(0.01)$ & $(0.01)$ & $(0.01)$ & $(0.01)$ \\
\hline \multirow[t]{2}{*}{ Post-primary +} & 0.94 & -1.90 & 4.76 & $-2.46^{*}$ \\
\hline & $(0.03)$ & $(0.02)$ & $(0.04)$ & $(0.01)$ \\
\hline \multirow[t]{2}{*}{ Unknown education } & $3.42 * *$ & $2.93 * *$ & $3.03 * *$ & 0.25 \\
\hline & $(0.02)$ & $(0.01)$ & $(0.01)$ & $(0.01)$ \\
\hline \multirow[t]{2}{*}{ Had/has non-farm occupation } & $3.85 * *$ & 5.34 & 1.45 & $2.27 * *$ \\
\hline & $(0.02)$ & $(0.04)$ & $(0.01)$ & $(0.01)$ \\
\hline \multirow[t]{2}{*}{ Absent from household } & & 1.16 & & \\
\hline & & $(0.01)$ & & \\
\hline Absent from household \& had/has non-farm & & 0.86 & & \\
\hline occupation & & $(0.04)$ & & \\
\hline Mother's characteristics & & & & \\
\hline No education & & & & \\
\hline Primary & 0.24 & & -0.18 & 0.49 \\
\hline & $(0.01)$ & & $(0.01)$ & $(0.01)$ \\
\hline Post-primary + & -3.17 & & 0.65 & \\
\hline & $(0.03)$ & & $(0.03)$ & \\
\hline Unknown education & -2.19 & & $-2.04 * *$ & 0.47 \\
\hline & $(0.01)$ & & $(0.01)$ & $(0.01)$ \\
\hline $\mathrm{Had} /$ has non-farm occupation & 3.81 & $39.82 * *$ & & $10.77 * *$ \\
\hline & $(0.06)$ & $(0.18)$ & & $(0.07)$ \\
\hline Absent from household & & $2.75^{*}$ & & \\
\hline & & $(0.02)$ & & \\
\hline Absent from household \& had/has non-farm & & $-6.89 * *$ & & \\
\hline occupation & & $(0.01)$ & & \\
\hline Household's characteristics & & & & \\
\hline Agricultural land holdings & $1.00 * *$ & 0.11 & $0.77 * *$ & -0.02 \\
\hline & $(0.003)$ & $(0.002)$ & $(0.002)$ & $(0.001)$ \\
\hline Dependents ratio & $3.38 *$ & 2.90 & $2.46^{*}$ & 0.96 \\
\hline & $(0.02)$ & $(0.02)$ & $(0.01)$ & $(0.01)$ \\
\hline Number of livestock heads & $0.05 * *$ & -0.001 & 0.04 & -0.001 \\
\hline & $(0.0002)$ & $(0.0002)$ & $(0.0001)$ & $(0.0002)$ \\
\hline
\end{tabular}




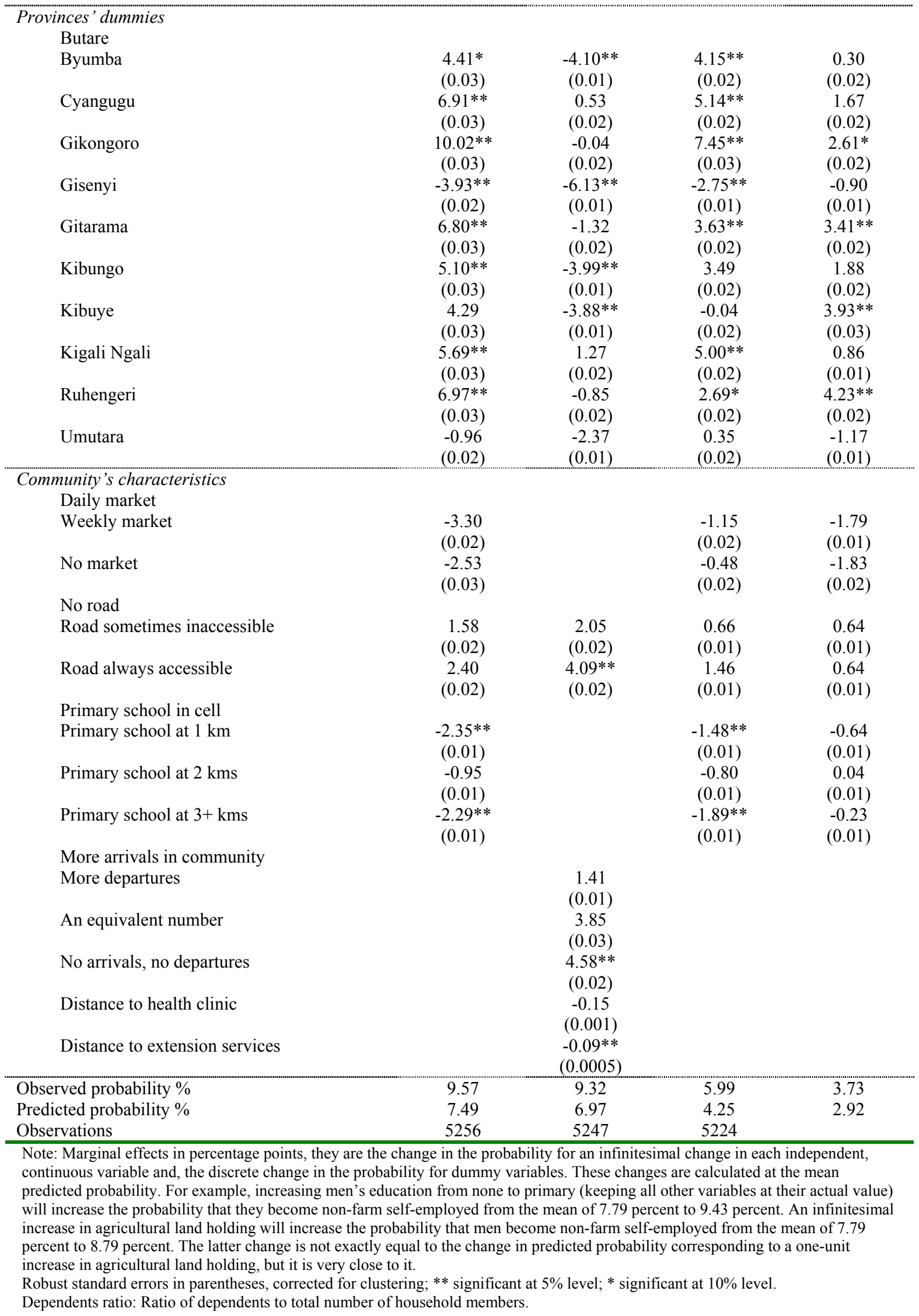


Table 11: Participation in the non-farm sector for rural women (Marginal effects in percentage points)

\begin{tabular}{|c|c|c|c|c|}
\hline & $\begin{array}{l}\text { Self- } \\
\text { employment }\end{array}$ & $\begin{array}{l}\text { Wage } \\
\text { employment }\end{array}$ & $\begin{array}{l}\text { Non-farm } \\
\text { enterprise has } \\
\text { assets }\end{array}$ & $\begin{array}{c}\text { Non-farm } \\
\text { enterprise has } \\
\text { no asset }\end{array}$ \\
\hline \multicolumn{5}{|l|}{ Personal characteristics } \\
\hline \multicolumn{5}{|l|}{ No education } \\
\hline \multirow[t]{2}{*}{ Primary } & 0.41 & $1.06 * *$ & $0.51 *$ & -0.06 \\
\hline & $(0.01)$ & $(0.003)$ & $(0.003)$ & $(0.004)$ \\
\hline \multirow[t]{2}{*}{ Post-primary } & $8.58 * *$ & $11.40 * *$ & $6.06 * *$ & 1.58 \\
\hline & $(0.03)$ & $(0.03)$ & $(0.02)$ & $(0.02)$ \\
\hline \multirow[t]{2}{*}{ Secondary +} & -1.10 & $39.31 * *$ & -0.30 & -0.50 \\
\hline & $(0.01)$ & $(0.06)$ & $(0.01)$ & $(0.01)$ \\
\hline \multirow[t]{2}{*}{ Age } & -0.02 & $-0.04 * *$ & -0.01 & -0.01 \\
\hline & $(0.0002)$ & $(0.0001)$ & $(0.0001)$ & $(0.0002)$ \\
\hline \multicolumn{5}{|l|}{ Head of household } \\
\hline \multirow[t]{2}{*}{ Spouse } & $-1.33 * *$ & 0.07 & -0.50 & -0.62 \\
\hline & $(0.01)$ & $(0.004)$ & $(0.003)$ & $(0.004)$ \\
\hline \multirow[t]{2}{*}{ Close family } & -1.71 & -0.78 & -0.61 & -1.02 \\
\hline & $(0.01)$ & $(0.01)$ & $(0.01)$ & $(0.01)$ \\
\hline \multirow[t]{2}{*}{ Other relatives } & $-2.21 * *$ & 0.63 & -0.81 & -1.12 \\
\hline & $(0.01)$ & $(0.01)$ & $(0.003)$ & $(0.005)$ \\
\hline \multirow[t]{2}{*}{ Domestic \& other } & $-2.80 * *$ & $23.82 * *$ & $-1.15^{*}$ & -0.66 \\
\hline & $(0.01)$ & $(0.08)$ & $(0.003)$ & $(0.01)$ \\
\hline \multirow[t]{2}{*}{ Migrated to current location } & $1.66^{* *}$ & -0.31 & $1.35 * *$ & -0.13 \\
\hline & $(0.01)$ & $(0.003)$ & $(0.005)$ & $(0.004)$ \\
\hline \multicolumn{5}{|l|}{ Always lived here } \\
\hline Migrated at some point \& came back & & $\begin{array}{c}-0.01 \\
(0.003) \\
\end{array}$ & & \\
\hline \multicolumn{5}{|l|}{ Father's characteristics } \\
\hline \multirow[t]{2}{*}{$\mathrm{Had} /$ has non-farm occupation } & -1.41 & $3.32 * *$ & $1.05 * *$ & 0.55 \\
\hline & $(0.02)$ & $(0.02)$ & $(0.01)$ & $(0.01)$ \\
\hline \multirow[t]{2}{*}{ Absent from household } & $1.41 * *$ & -0.35 & 0.55 & $0.81^{*}$ \\
\hline & $(0.01)$ & $(0.005)$ & $(0.004)$ & $(0.004)$ \\
\hline \multirow{2}{*}{$\begin{array}{l}\text { Absent from household \& had/has non-farm } \\
\text { occupation }\end{array}$} & 5.64 & -0.75 & & \\
\hline & $(0.05)$ & $(0.004)$ & & \\
\hline \multicolumn{5}{|l|}{ Mother's characteristics } \\
\hline No education & & & & \\
\hline Primary & 0.17 & & 0.50 & -0.38 \\
\hline & $(0.01)$ & & $(0.004)$ & $(0.004)$ \\
\hline Post-primary + & 1.28 & & 2.36 & \\
\hline & $(0.04)$ & & $(0.03)$ & \\
\hline Unknown education & 1.65 & & 0.22 & $1.27 *$ \\
\hline & $(0.01)$ & & $(0.01)$ & $(0.01)$ \\
\hline Had/has non-farm occupation & 2.07 & $32.25 * *$ & $3.04 *$ & $6.42 * *$ \\
\hline & $(0.04)$ & $(0.11)$ & $(0.03)$ & $(0.03)$ \\
\hline Absent from household & -1.80 & -0.46 & -0.25 & -1.38 \\
\hline & $(0.02)$ & $(0.01)$ & $(0.01)$ & $(0.01)$ \\
\hline Absent from household \& had/has non-farm & $12.77 *$ & $-1.15^{* *}$ & & \\
\hline occupation & $(0.11)$ & $(0.002)$ & & \\
\hline Household's characteristics & & & & \\
\hline Agricultural land holdings & -0.003 & 0.02 & 0.06 & $-0.36^{*}$ \\
\hline & $(0.001)$ & $(0.0004)$ & $(0.001)$ & $(0.002)$ \\
\hline Dependents ratio & 0.44 & 0.44 & 0.40 & -0.08 \\
\hline & $(0.01)$ & $(0.01)$ & $(0.01)$ & $(0.01)$ \\
\hline Number of livestock heads & $0.03 * *$ & 0.002 & $0.01 * *$ & 0.003 \\
\hline & $(0.0001)$ & $(0.0001)$ & $(0.00005)$ & $(0.0001)$ \\
\hline Provinces' dummies & & & & \\
\hline Butare & & & & \\
\hline Byumba & -0.97 & $-0.67 *$ & -0.21 & -0.51 \\
\hline & $(0.01)$ & $(0.003)$ & $(0.01)$ & $(0.01)$ \\
\hline
\end{tabular}




\begin{tabular}{|c|c|c|c|c|}
\hline Cyangugu & $\begin{array}{c}0.29 \\
(0.01)\end{array}$ & $\begin{array}{c}-0.54 \\
(0.004)\end{array}$ & $\begin{array}{c}0.31 \\
(0.01)\end{array}$ & $\begin{array}{c}0.05 \\
(0.01)\end{array}$ \\
\hline \multirow[t]{2}{*}{ Gikongoro } & $4.56^{* *}$ & 0.72 & $1.48 * *$ & $3.26 * *$ \\
\hline & $(0.02)$ & $(0.01)$ & $(0.01)$ & $(0.02)$ \\
\hline \multirow[t]{2}{*}{ Gisenyi } & $-3.48 * *$ & $-1.39 * *$ & $-1.39 * *$ & -1.41 \\
\hline & $(0.01)$ & $(0.002)$ & $(0.003)$ & $(0.01)$ \\
\hline \multirow[t]{2}{*}{ Gitarama } & 0.71 & $-0.65^{*}$ & -0.37 & $1.98 *$ \\
\hline & $(0.01)$ & $(0.003)$ & $(0.005)$ & $(0.01)$ \\
\hline \multirow[t]{2}{*}{ Kibungo } & -0.001 & 0.01 & -0.60 & 1.67 \\
\hline & $(0.01)$ & $(0.005)$ & $(0.01)$ & $(0.02)$ \\
\hline \multirow[t]{2}{*}{ Kibuye } & 2.63 & $-1.06 * *$ & -0.73 & $4.01 * *$ \\
\hline & $(0.02)$ & $(0.002)$ & $(0.005)$ & $(0.02)$ \\
\hline \multirow[t]{2}{*}{ Kigali Ngali } & $2.91 *$ & -0.64 & 0.48 & $3.35 * *$ \\
\hline & $(0.02)$ & $(0.003)$ & $(0.01)$ & $(0.02)$ \\
\hline \multirow[t]{2}{*}{ Ruhengeri } & $7.17 * *$ & -0.54 & 0.86 & $7.02 * *$ \\
\hline & $(0.03)$ & $(0.005)$ & $(0.01)$ & $(0.03)$ \\
\hline \multirow[t]{2}{*}{ Umutara } & 1.37 & -0.20 & 0.78 & 0.67 \\
\hline & $(0.02)$ & $(0.01)$ & $(0.01)$ & $(0.01)$ \\
\hline \multicolumn{5}{|l|}{ Community's characteristics } \\
\hline \multicolumn{5}{|l|}{ More arrivals in community } \\
\hline \multirow[t]{2}{*}{ More departures } & 0.24 & & 0.17 & 0.11 \\
\hline & $(0.01)$ & & $(0.003)$ & $(0.004)$ \\
\hline \multirow[t]{2}{*}{ An equivalent number } & 2.96 & & 1.49 & 1.34 \\
\hline & $(0.02)$ & & $(0.01)$ & $(0.02)$ \\
\hline \multirow{2}{*}{ No arrivals, no departures } & 1.11 & & 0.48 & 0.49 \\
\hline & $(0.01)$ & & $(0.01)$ & $(0.01)$ \\
\hline \multicolumn{5}{|l|}{ Daily market } \\
\hline \multirow[t]{2}{*}{ Weekly market } & -1.59 & -0.73 & $-0.83^{*}$ & -0.09 \\
\hline & $(0.01)$ & $(0.005)$ & $(0.004)$ & $(0.01)$ \\
\hline \multirow[t]{2}{*}{ No market } & $-3.17 * *$ & -1.17 & $-1.73 * *$ & -0.68 \\
\hline & $(0.02)$ & $(0.01)$ & $(0.01)$ & $(0.01)$ \\
\hline \multicolumn{5}{|l|}{ No road } \\
\hline \multirow[t]{2}{*}{ Road sometimes inaccessible } & 0.61 & -0.05 & 2.13 & -0.41 \\
\hline & $(0.01)$ & $(0.01)$ & $(0.02)$ & $(0.01)$ \\
\hline \multirow[t]{2}{*}{ Road always accessible } & $1.94^{*}$ & -0.09 & $2.01 *$ & 0.38 \\
\hline & $(0.01)$ & $(0.01)$ & $(0.01)$ & $(0.01)$ \\
\hline \multirow[t]{2}{*}{ Distance to extension services } & $-0.06^{* *}$ & & $-0.05 * *$ & -0.01 \\
\hline & $(0.0003)$ & & $(0.0002)$ & $(0.0002)$ \\
\hline \multirow[t]{2}{*}{ Distance to health clinic } & & $-0.07 *$ & & \\
\hline & & $(0.0004)$ & & \\
\hline Observed probability $\%$ & 4.77 & 2.90 & 2.27 & 2.52 \\
\hline Predicted probability $\%$ & 3.54 & 1.12 & 1.25 & 1.79 \\
\hline Observations & 6789 & 6803 & 6789 & 6747 \\
\hline
\end{tabular}




\section{Bibliography}

Ahituv A. and Kimhi A. (2002), "Off-farm work and capital accumulation decisions of farmers over the life-cycle: the role of heterogeneity and state dependence", Journal of Development Economics, vol. 68, pp. 329-353.

Barrett C.B., Reardon T., and Webb P. (2001), "Nonfarm income diversification and household livelihood strategies in rural Africa: concepts, dynamics, and policy implications", Food Policy, vol. 26, pp. 315-331.

Becker S. and Ichino A. (2002), "Estimation of average treatment effects based on propensity scores", Stata Journal, vol. 2, no. 4, pp. 358-377.

Clay D., Kampayana T. and Kayitsinga J. (1990), "Inequality and the emergence of nonfarm employment in Rwanda", Revised and published as a chapter in "Inequality and the Emergence of Nonfarm Employment in Rwanda." By Daniel C. Clay and T.

Kampayana, in Nan E. Johnson and Ching-li Wang (eds.) Changing Rural Social Systems: Adaptation and Survival. East Lansing: Michigan State University Press. 1997.

Colletta N. and Cullen M. (2000), "Violent conflict and the transformation of social capital", The World Bank, Washington DC.

Dehejia R. and Wahba S. (1999), "Causal effects in nonexperimental studies: reevaluating the evaluation of training programs", Journal of the American Statistical Association, vol. 94, no. 448, pp. 1053-62.

Dunn T. and Holtz-Eakin D. (2000), "Financial capital, human capital, and the transition to self-employment: evidence from intergenerational links", Journal of Labor Economics, vol. 18 , no. 2 , pp. $282-305$.

Greene W. (2003), “Econometric analysis”, Prentice Hall.

Heckman J., Lalonde R., and Smith J. (1999), "The economics and econometrics of active labor market programs", in Handbook of labor economics, vol. 3A, Ashenfelter O., Card D. (eds.), pp. 1865-2097, North Holland.

Lanjouw J. and Lanjouw P. (2001), "The rural non-farm sector: issues and evidence from developing countries", Agricultural Economics, vol. 26, pp. 1-23.

Lanjouw P., Quizon J. and Sparrow R. (2001), "Non-agricultural earnings in peri-urban areas of Tanzania: evidence from household survey data", Food Policy, vol. 26, pp. 385403.

Levine D. and Painter G. (2003), "The schooling costs of teenager out-of-wedlock childbearing: analysis with a within-school propensity-score-matching estimator", Review of Economics and Statistics, vol. 85, no. 4, pp. 884-900. 
Ministry of Finance (2002), "A profile of poverty in Rwanda. An analysis based on the results of the Household Living Conditions Survey 1999-2001", Ministry of Finance and Economic Planning, Republic of Rwanda.

Reardon T. (1997), "Using evidence of household income diversification to inform study of the rural nonfarm labor market in Africa", World Development, vol. 25, no. 5, pp. 735747.

Rosenbaum P. and Rubin D. (1983), "The central role of the propensity score in observational studies for causal effects”, Biometrika, vol. 70, pp. 41-55.

Sianesi B. (2001), "Differential effects of Swedish active labour market programmes for unemployed adults during the 1990s", IFS working paper, London.

The government of Rwanda (June 2002), Poverty reduction strategy paper, National Poverty Reduction Programme, Ministry of Finance and Economic Planning.

Vijverberg W. (1991), "Measuring income from family enterprises with household surveys", Living Standard Measurement Study Working Paper no. 84, World Bank, Washington D.C.

Woldenhanna T. and Oskam A. (2001), "Income diversification and entry barriers: evidence from the Tigary region of northern Ethiopia", Food Policy, vol. 26, pp. 351365 .

World Bank (1992), "The social dimensions of adjustment integrated survey. A survey to measure poverty and understand the effects of policy change on households", SDA Working Paper No. 14 - Surveys and Statistics, The World Bank. 


\section{Annex 1: Average shares of income sources by quintile in all areas (\%)}

Table A 1: Average shares of income sources by quintile in all areas (\%)

\begin{tabular}{lccccc}
\hline & $1^{\text {st }}$ quintile & $2^{\text {d }}$ quintile & $3^{\mathrm{d}}$ quintile & $4^{\text {th }}$ quintile & $5^{\text {th }}$ quintile \\
\hline Share of non-farm wage employment & 3.27 & 2.49 & 6.08 & 8.84 & 29.27 \\
Share of agricultural employment & 14.72 & 24.77 & 6.50 & 4.69 & 3.20 \\
Share of net farm income & 96.35 & 79.83 & 77.03 & 79.16 & 43.49 \\
Share of net non-farm enterprise income & 3.98 & 4.19 & 6.61 & 6.90 & 17.70 \\
Share of other incomes & 2.76 & 3.74 & 3.53 & 3.77 & 5.09 \\
Share of net remittance & -21.08 & -15.02 & 0.25 & -3.36 & 1.25 \\
& & & & & \\
Number of observations & 996 & 1086 & 1216 & 1267 & 1690 \\
\hline
\end{tabular}




\section{Annex 2: Description of variables}

The analysis uses information on individuals aged 15 to 64 years old. The descriptive analysis uses the weighted data.

There are two main ways of identifying non-farm employment and income in the household survey. One is through the individual level variables; individuals are asked to specify their work status in their primary and secondary occupation (Paid employee, employer, self-employed, domestic help and apprentice). It is therefore possible to identify those employer and self-employed who are working in non-agricultural occupation. It is further possible to check whether they receive money for their work and how much. There is a limitation in that payments in kind are not recorded.

The second way is to use the information reported in the non-farm employment section of the survey. Individuals are asked whether the household has a non-farm enterprise and it is possible to identify which household member is responsible for it and which other members are working in it. It is also possible to record annual net income for each enterprise. We observe that all those who report being self-employed or employer do not always report a non-farm enterprise and vice versa. Both sources should therefore be combined in order to have a more precise idea. For reasons indicated below, it is however not possible. In addition, it is important to look at both primary and secondary occupations. We therefore count people in the non-farm sector even if it is only their secondary occupation. If both occupations are reported to be in the non-farm sector, we use the information on the primary occupation. Finally the fact of belonging to rural areas is measured through the residence of individuals (so that non-farm wage workers who are counted here in rural areas may actually be commuting to an urban area to work).

\begin{tabular}{ll}
\hline \multicolumn{1}{c}{ Variable name } & \multicolumn{1}{c}{ Categories or units } \\
\hline Status for any & No occupation, Agricultural \\
occupation & sector, Non-farm enterprise, \\
& Non-farm wage worker, At \\
& school
\end{tabular}

Construction

Non-farm enterprise: those who report being self-employed or employer in a non-agricultural occupation in the employment section of the questionnaire whether it is in their primary or secondary occupation. Add those who report being responsible for a non-farm enterprise in the section of the questionnaire specific to non-farm enterprises.

Non-farm wage worker: Are not in the previous category AND report being wage employed (either paid employee, apprentice or domestic help) in a non-agricultural occupation in the employment section of the questionnaire whether it is in their primary or secondary occupation. Add those who report working in the household's non-farm enterprise in the section of the questionnaire specific to non-farm enterprises. Agricultural sector: Are not in the two previous categories and have an agricultural occupation.

No occupation: Are not in the previous categories and report not holding any occupation nor being at school. At school: Are not in the previous categories and are at school.

\begin{tabular}{ll}
$\begin{array}{l}\text { Status for primary } \\
\text { occupation }\end{array}$ & Same as above \\
& $\begin{array}{l}\text { Non-farm enterprise: those who report being self-employed } \\
\text { or employer in a non-agricultural occupation in their primary } \\
\text { occupation in the employment section of the questionnaire. } \\
\text { Non-farm wage worker: Are not in the previous category } \\
\text { AND report being wage employed (either paid employee, } \\
\text { apprentice or domestic help) in a non-agricultural occupation } \\
\text { in their primary occupation in the employment section of the }\end{array}$ \\
\hline
\end{tabular}


questionnaire.

Agricultural sector: Are not in the two previous categories and have an agricultural primary occupation.

No occupation: Are not in the previous categories and report not holding any occupation nor being at school.

At school: Are not in the previous categories and are at school.

\begin{tabular}{ll}
\hline $\begin{array}{l}\text { Status for secondary } \\
\text { occupation }\end{array}$ & Same as above \\
\hline $\begin{array}{l}\text { Money wage primary } \\
\text { occupation }\end{array}$ & Rwf \\
\end{tabular}

Same as above for those holding a secondary occupation

Questions 11 and 12 of section $4 \mathrm{~b}$ (employment) of questionnaire.

Did you receive any money for this work?

What was the last amount received?

$\begin{array}{ll}\text { Money wage } & \text { Rwf } \\ \text { secondary occupation } & \end{array}$

Gross income from Rwf

large scale crops crops using sharecropping.

Questions 11 and 12 of section 4c (employment) of

questionnaire.

Same wording as above.

Calculate : portion=quantity produced - quantity used for

seeding - quantity used for processing.

Income $=$ value $^{*}$ (portion/quantity produced)

With value from question: "If you had sold all the harvest in the last 12 months, what would be the total value?"

Gross income from Rwf For each enterprise (maximum 3 per household), calculate

non-farm enterprise

the annualized revenue in the following way:

Revenue in previous two weeks (or usual revenue in a twoweek period if firm was not operating in the previous two weeks) * number of two-week periods where the firm was operating in last 12 months. Then add up revenues from all three enterprises.

Revenue in previous two weeks is sum of amount received from sale of goods and services produced by the enterprise, of amount received for payments in the form of goods and services, and of amount consumed by household instead of being sold. (Section 10d)

\begin{tabular}{|c|c|c|}
\hline Land holdings & ha & $\begin{array}{l}\text { Section 8c question 4: area in ha of land exploited or } \\
\text { possessed except land rented out, given for sharecropping or } \\
\text { lent. }\end{array}$ \\
\hline $\begin{array}{l}\text { Household } \\
\text { participation in non- } \\
\text { farm sector }\end{array}$ & $\begin{array}{l}\text { No non-farm enterprise in } \\
\text { large scale farm household, } \\
\text { Both non-farm enterprise and } \\
\text { large scale farm, Only non- } \\
\text { farm enterprise and no large } \\
\text { scale farm, No non-farm } \\
\text { enterprise and no large scale } \\
\text { farm }\end{array}$ & $\begin{array}{l}\text { This variable is based on data on income from non-farm } \\
\text { enterprises and from large-scale crops. } \\
\text { No non-farm enterprise in large-scale farm household: have } \\
\text { income from large-scale crops but none from non-farm } \\
\text { enterprise. } \\
\text { Similarly for other categories. }\end{array}$ \\
\hline Education & $\begin{array}{l}\text { No education, Primary, } \\
\text { Post-primary, Secondary, } \\
\text { Further education }\end{array}$ & $\begin{array}{l}\text { Primary: attended primary school (but might not have } \\
\text { completed it) } \\
\text { Secondary: attended secondary school } \\
\text { Etc. }\end{array}$ \\
\hline Occupational choice & $\begin{array}{l}\text { Farmers only } \\
\text { Agricultural worker (and } \\
\text { potentially farmer) } \\
\text { Non-farm wage worker (and } \\
\text { potentially farmer) } \\
\text { Non-farm self-employed (and } \\
\text { potentially farmer) } \\
\text { Other combinations of main } \\
\text { and secondary occupations } \\
\text { No occupations }\end{array}$ & $\begin{array}{l}\text { The categories are obtained from the employment section of } \\
\text { the questionnaire (section 4). Individuals are asked their } \\
\text { current two main occupations and their status in those } \\
\text { occupations. Farmers only: those who report working in the } \\
\text { agricultural sector and being self-employed, in the main and } \\
\text { or secondary occupation if they have one. } \\
\text { Agricultural worker (and potentially farmer): those who } \\
\text { report working in the agricultural sector and being wage } \\
\text { employed, in the main and/or secondary occupation. } \\
\text { Non-farm wage worker (and potentially farmer): those who } \\
\text { report working in the non-agricultural sector and being wage }\end{array}$ \\
\hline
\end{tabular}


employed, in the main and/or secondary occupation.

Non-farm self-employed (and potentially farmer): those who report working in the non-agricultural sector and being selfemployed, in the main and/or secondary occupation.

Other combinations of main and secondary occupations No occupations

\begin{tabular}{lll}
\hline Occupational choice & $\begin{array}{l}\text { Same as above except instead } \\
\text { of Non-farm self-employed } \\
\text { (and potentially farmer), we } \\
\text { have Non-farm self-employed } \\
\text { with assets (and potentially } \\
\text { farmer), Non-farm self- }\end{array}$ & $\begin{array}{l}\text { Same as above. The additional two categories are constructed } \\
\text { by matching information on non-farm enterprises (section } 10 \\
\text { of questionnaire). The information on assets is used if the } \\
\text { occupation code of the individuals matches the occupation } \\
\text { code of the non-farm enterprise. Observations which do not } \\
\text { match are dropped. } \\
\text { potentially farmer). }\end{array}$ \\
\hline
\end{tabular}

\section{Construction of household income variable}

Income from farm comes from adding and subtracting the following items

Sales of livestock

Purchase of livestock

Loss of livestock

Amount from renting out livestock

Sales of livestock products

Purchase of products used for raising livestock

Cost of land used for livestock

Amount from renting out tools

Amount from selling out tools

Total value of large crops (not reused or paid out for sharecropping)

Total value of small crops

Other sources of income from agriculture

Costs associated with production of crops

Amount obtained from renting land out

Amount received from sharecropping

Cost of renting agricultural land

Following Vijverberg (1991), income from non-farm enterprise comes from

Amount used for household purpose

Amount used for own use

Amount paid out to other households

Amount saved

Amount used for other purposes

Value of goods and services produced by non-farm enterprise and consumed by the household 


\section{Annex 3: Observable characteristics used in matching methodology.}

\section{Matching of individuals}

\section{Personal}

Gender

Suffer from disease and/or injury

Participated in housework in last 7 day (fetching wood, fetching water, shopping, cooking, cleaning etc.)

Did they ever participate in training or placements

Educational level

Age

Status in household

Time since last migration

Whether mother (father) lives in household

Educational level of mother (father)

Participation of mother (father) in the non-farm sector

\section{Household}

Number of dependents (14 and younger) divided by total number of household members

Agricultural land holdings of household

Livestock holdings of household

Household assets

Can use their land as collateral

Can sell their land

Was home owner the previous year

\section{Community}

Average size of agricultural landholdings in community

Presence of an agricultural extension in the community

Presence of a primary school in the community

Presence of a market in the community

Distance to this market

Electricity in the community

Presence of an association of farmers or breeders in the community

Access to a road

Presence and distance to a health clinic

Access to credit for rural development

Whether farmers in the community use fertilizer or pesticides

Whether the community has access to a network of water supply

Province 


\section{Matching of households}

Age of head of household

Was home owner the previous year

One of its members has taken up a loan from a "modern" institution

One of its members has taken up a loan from a "traditional" institution

Household assets

Whether the mother (father) of the head of household participated in the non-farm sector

Educational attainment of mother (father) of head of household

Educational attainment of the head of household

Sex of the head of household

Type of household (Monoparental headed by a woman, by a man, biparental, etc.)

Number of household members

Number of children aged seven or less

Number of children aged 7 to 14

Number of members aged 15 to 65

Maximum education reached by the households' adults.

Agricultural land holdings of household

Livestock holdings of household

Can use their land as collateral

Can sell their land

Province

Presence of an agricultural extension in the community

Presence of a primary school in the community

Presence of a market in the community

Distance to this market

Electricity in the community

Presence of an association of farmers or breeders in the community

Access to a road

Presence and distance to a health clinic

Access to credit for rural development

Whether farmers in the community use fertilizer or pesticides

Whether the community has access to a network of water supply 